\title{
MEMFASILITASI MINAT BACA MASYARAKAT MELALUI PERPUSTAKAAN FISIK DAN DIGITAL DUSUN KARANGMOJO
}

\author{
Yudhy Widya Kusumo', Ratna Widyaningsih², Ristiyan Ragil P3, Dewi \\ Nur K4, Intan Zuhaira5 \\ 1,2,3,4,5Universitas Pembangunan Nasional "Veteran" Yogyakarta \\ 1E-mail address: yudhy.widya@upnyk.ac.id; 2E-mail address: \\ ratna.widyaningsih@upnyk.ac.id
}

\begin{abstract}
The current Covid-19 pandemic has caused children to study online. Thus, children are increasingly opening and playing gadgets. Not a few children spend their time just playing 'online games'. Adults who do activities or work from home on average spend their time using gadgets. With this phenomenon, people's interest in reading has decreased. One way to increase people's interest in reading is by making the Karangmojo Village Community Reading Corner. In the era of globalization as it is now, this Community Reading Corner not only provides a physical library but also provides a digital library that can be accessed via the Handy Library aplication by the people of Karangmojo Village.
\end{abstract}

Keywords: community reading corner, physical library, digital

\begin{abstract}
Abstrak
Masa Pandemi Covid-19 seperti sekarang ini menyebabkan anak-anak melakukan pembelajaran secara daring. Dengan demikian anak-anak semakin sering membuka dan memainkan gadget. Tidak sedikit anak yang menghabiskan waktunya hanya dengan bermain 'game online'. Masyarakat dewasa yang melakukan kegiatan ataupun pekerjaan dari rumah rata-rata menghabiskan waktunya dengan menggunakan gadget. Adanya fenomena ini, minat baca masyarakat pun menurun. Salah satu cara untuk meningkatkan minat baca masyarakat yaitu dengan pembuatan Taman Bacaan Masyarakat Dusun Karangmojo. Di era globalisasi seperti sekarang, Taman Bacaan Masyarakat ini selain menyediakan Perpustakaan fisik tetapi juga menyediakan Perpustakaan Digital yang bisa diakses melalui aplikasi Handy Library oleh masyarakat Dusun Karangmojo.
\end{abstract}

Kata Kunci: taman bacaan masyarakat, perpustakaan fisik, digital 


\section{PENDAHULUAN}

Masa kanak-kanak dan masa muda adalah masa yang paling tepat untuk mengasah kemampuan serta pembentukan karakter kepribadian seseorang. Pendidikan pelajaran ataupun ketrampilan yang baik, pembimbingan yang kontinyu, serta tersedianya fasilitas penunjang pendidikan sangat dibutuhkan demi membantu tercapainya kemampuan anak secara optimal. Wawasan luas juga menjadi salah satu hal yang diharapkan dari adanya faktor-faktor penunjang tersebut. Anak nantinya akan tumbuh menjadi seseorang yang mempunyai kompetensi di bidangnya dan berwawasan luas. Kedua hal tersebut menjadi sebagian bekal seseorang untuk menjadi dan mampu bersaing dalam era globalisasi dan ditengah-tengah masa pandemi.

Kegiatan anak-anak usia sekolah di masa pandemi Covid-19 ini menjadi kurang terjadwal karena anak-anak hanya diberi tugas sekolah dengan kondisi bebas. Peran orang tua sangatlah diperlukan. Namun, tidak semua orang tua mampu mengawasi anaknya pada jam biasanya belajar di sekolah. Orang tua yang bekerja akan kesulitan mengawasi kegiatan anak. Penggunaan gadget yang digunakan untuk pendukung kegiatan belajar-mengajar dari sekolah saat ini memiliki dampak negatif lain yaitu bermain game dan menonton video-video yang kurang bermanfaat. Para orangtua mengeluhkan penggunaan gadget untuk bermain game lebih banyak dibandingkan waktu mengerjakan tugas sekolah.

Pada era globalisasi seperti sekarang, pendidikan merupakan sesuatu yang sangat penting. Karena pendidikan merupakan akar dari peradaban sebuah bangsa. Untuk memperoleh pendidikan, banyak cara yang dapat kita capai, diantaranya melalui perpustakaan. Di perpustakaan ini dapat memperoleh berbagai sumber informasi salah satunya dengan cara membaca. Membaca merupakan cara yang sangat baik untuk menambah wawasan, memperbanyak kosa kata maupun meningkatkan ilmu pengetahuan dan teknologi.

Dalam Undang-Undang Republik Indonesia Nomor 43 Tahun 2007 Pasal 3 tentang Perpustakaan, dinyatakan bahwa fungsi perpustakaan sebagai wahana pendidikan, penelitian, pelestarian, informasi dan rekreasi untuk meningkatkan kecerdasan dan keberdayaan bangsa. Dengan fungsi yang dimiliki oleh perpustakaan yang diantaranya sebagai wahana pendidikan dan pusat informasi maka perpustakaan harus didukung oleh perangkat yang 
dapat mempermudah dalam mencari informasi yang dibutuhkan.

Adanya perpustakaan setidaknya memberikan peran kepada masyarakat luas untuk bisa memberikan bahan bacaan dan menyediakan fasilitas perkembangan ilmu pengetahuan. Tidak semua orang mampu membeli buku, apalagi bagi sebagian besar masyarakat kita, konsumsi buku merupakan kebutuhan yang kesekian dibandingkan kebutuhan lain. Sehingga, yang diperlukan adalah semangat keingintahuan dan membaca agar bisa memanfaatkan segala pengetahuan yang ada di perpustakaan.

Perpustakaan digital menjadi salah satu opsi untuk membuat perpustakaan yang ramah dikantong bagi masyarakat luas. Perpustakaan Digital merupakan salah satu alternatif yang dapat dilakukan perpustakaan untuk meningkatkan layanan perpustakaannya. Karena dengan sistem digital ini, perpustakaan dapat memformat informasi yang tersedia dari format tercetak menjadi format elektronis atau digital. Hal ini merupakan jawaban bagi pengguna yang menginginkan informasi yang terkemas secara singkat, padat dan akurat. Idealnya, setiap perpustakaan memanfaatkan kecanggihan teknologi informasi untuk mendukung pengelolaan koleksi perpustakaan.
Perpustakaan digital dapat dibuat menggunakan sistem membagi file melalui flashdisk. Masyarakat dapat mengunduh atau menyalin softfile dalam bentuk .pdf yang dikses melalui smartphone maupun PC yang ada. Tidak hanya kalangan dewasa, namun anakanak yang sudah terfasilitasi smartphone dapat mengakses untuk mencari buku yang diperlukan.

Perpustakaan merupakan jantung dari suatu institusi pendidikan karena perpustakaan mengkoleksi berbagai macam buku dan jurnal dari berbagai disiplin ilmu pengetahuan yang sangat diperlukan oleh suatu lembaga pendidikan. Tidak hanya menyedikan layanan sumber belajar bagi mahasiswa, namun LPPM UPN "Veteran" Yogyakarta juga memiliki program khusus dalam memberikan layanan sumber belajar bagi masyarakat dari berbagai kalangan. Dalam hal ini, Taman Bacaan Masyarakat (TBM) merupakan salah satu layanan pendidikan yang dapat dimanfaatkan oleh masyarakat dalam mengembangkan dan meningkatkan budaya membaca.

Berdasarkan info Dukuh Karangmojo yang menjabat, bahwa di Dusun ini belum ada sarana Taman Bacaan Masyarakat (TBM) yang dapat digunakan untuk menstimulus minat baca masyarakat. Padahal, menurut 
Abdul Holik (2013), perpustakaan yang ada di masyarakat bukan hanya tempat berkumpulnya buku-buku melainkan menjadi tempat aktifitas pendidikan, tempat berbagi solusi, sumber informasi, rekreasi serta rumah belajar kedua bagi masyarakat selain sekolah. Adanya taman bacaan ini diharapkan mampu mengimbangi penggunaan gadget yang dapat memberi pengaruh buruk pada generasi muda. Sekolah yang berada disana pun ditutup, sehingga tidak ada akses dalam peminjaman.

\section{METODE DAN PELAKSANAAN}

\section{Metode}

Tim

pelaksana

abdimas

sebelumnya telah menemui mitra yang diwakili oleh dukuh Dusun Karangmojo, dimana tim pelaksana dan mitra sepakat untuk saling mendukung pelaksanaan kegiatan ini. Hal ini ditunjukkan adanya surat kesediaan dukungan mitra terhadap kegiatan ini. Mitra akan memfasilitasi lokasi untuk pengadaaan Taman Bacaan Masyarakat Dusun Karangmojo.

Tim pelaksana akan melakukan langkah-langkah berikut dalam pelaksanaan kegiatan ini, yaitu :

1. Survei

Hal ini dilakukan untuk mengetahui kondisi lokasi yang akan dipilih menjadi taman bacaan masyarakat.
Lokasi yang dipilih adalah lokasi yang mudah dijangkau dan dapat terjaga dengan baik.

2. Pengumpulan dan Penyusunan Materi

Untuk mewujudkan Taman Bacaan Masyarakat (TBM) yang sesuai dengan lingkungan mitra, tim pelaksana mengumpulkan materi sebagai referensi.

3. Inventarisasi

Tim pelaksana mendata sarana dan prasarana yang sudah tersedia dan yang dibutuhkan untuk mewujudkan taman bacaan ini.

4. Pengadaan dan Pembuatan Fasilitas di TBM

Tim pelaksana melakukan pengadaan buku-buku yang disesuaikan kontennya yang meliputi dongeng rakyat Indonesia, pengetahuan umum, keahlian, agama. Pengadaan rak buku dan sistem peminjaman buku. Sistem peminjaman dilakukan dengan penjadwalan mengingat adanya pandemi maka perlu dilakukan sesuai protokol kesehatan. Kegiatan ini melibatkan karang taruna dan masyarakat yang ada di dusun Karangmojo.

5. Pengadaan dan Pembuatan Fasilitas Perpustakaan Digital Tim pelaksana melakukan pengadaan 
buku-buku online yang disesuaikan kontennya yang meliputi dongeng rakyat Indonesia, pengetahuan umum, keahlian, agama. Pengadaan perpustakaan digital ini memanfaatkan Web sebagai sarana mayarakat untuk mengakses bukubuku yang telah disediakan.

6. Sosialisasi, Pelaksanaan, Monitoring dan Evaluasi

Setelah persiapan sistem siap dijalankan, kemudian dilakukan sosialisasi kepada masyarakat melalui info dari dukuh setempat. Pelaksanaan dilakukan dan monitoring dan evaluasi terus dilakukan untuk menyempurnakan kegiatan ini.

7. Penyerahan TBM kepada Padukuhan Dusun Karangmojo

Hasil kegiatan ini diserahkan untuk masyarakat Dusun Karangmojo dan pengelolaan diserahkan kepada masyarakat setempat. Hal ini dilakukan agar terjadinya kesinambungan kegiatan setelah diserahkan ke Dusun Karangmojo.

8. Pembuatan Laporan, Publikasi dan Pendaftaran HKI dan ISBN produk Setelah kegiatan selesai, dokumentasi, luaran wajib dan laporan dikumpulkan untuk disusun dan diserahkan ke LPPM UPN "Veteran" Yogyakarta.

\section{Pelaksanaan Kegiatan}

Tim pelaksana sebelumnya telah menemui mitra yang diwakili oleh Kepala Dusun Karangmojo, dimana tim pelaksana dan mitra sepakat untuk saling mendukung pelaksanaan kegiatan ini. Hal ini ditunjukkan adanya surat kesediaan dukungan mitra terhadap kegiatan ini. Mitra akan memfasilitasi lokasi untuk pengadaaan taman bacaan masyarakat. Kegiatan pengabdian masyarakat ini akan dilaksanakan dalam waktu 8 bulan.

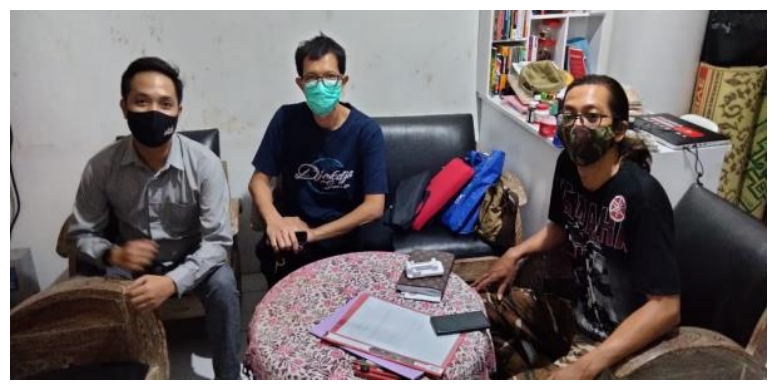

Gambar 4. Tim Pelaksana Abdimas

Bertemu dengan Kepala Dusun

Karangmojo

Tim pelaksana telah melakukan langkah-langkah berikut dalam pelaksanaan kegiatan ini yaitu :

1. Survei Lokasi Mitra

Hal ini dilakukan untuk mengetahui kondisi lokasi yang akan dipilih menjadi taman bacaan masyarakat. Lokasi yang dipilih adalah lokasi yang mudah dijangkau dan dapat terjaga dengan baik. Terdapat 3 lokasi yang menjadi kandidat tempat taman bacaan. Yang pertama kios 
berlokasi di RT 04 RW.01 (Gambar 5.a), namun karena pertimbangan lokasi agak jauh dari pemukiman, sehingga perawatan dan pemanfaatannya dinilai kurang efisien. Lokasi yang kedua berada di RT.11, salah seorang warga mengusulkan kediamannya sebagai lokasi taman bacaan. Secara keamanan dan akses, tempat ini cukup baik karena banyak dilewati warga dan berada di sekitar pemukiman. Namun pertimbangan jika pemilik rumah tidak berada di tempat, maka warga akan kesulitan mengunjungi tempat bacaan ini. Lokasi ketiga yaitu berada di RT.01 tepatnya di Mesjid Annur. Salah seorang pengurus mesjid mengusulkan agar taman bacaan bertempat di sini. Mesjid ini selain tempat ibadah, digunakan juga untuk tempat belajar mengaji anakanak. Mesjid ini merupakan mesjid yang besar di antara 4 mesjid di Dusun Karangmojo. Mesjid ini pun memiliki fasilitas wifi dimana selain waktu ibadah, beberapa anak berkumpul di sekitar mesjid untuk mendapatkan akses wifi ini. Tim pelaksana pengabdian bagi masyarakat kemudian melakukan diskusi dengan Kepala Dusun Karangmojo. Kepala Dusun kemudian menyetujui hal tersebut

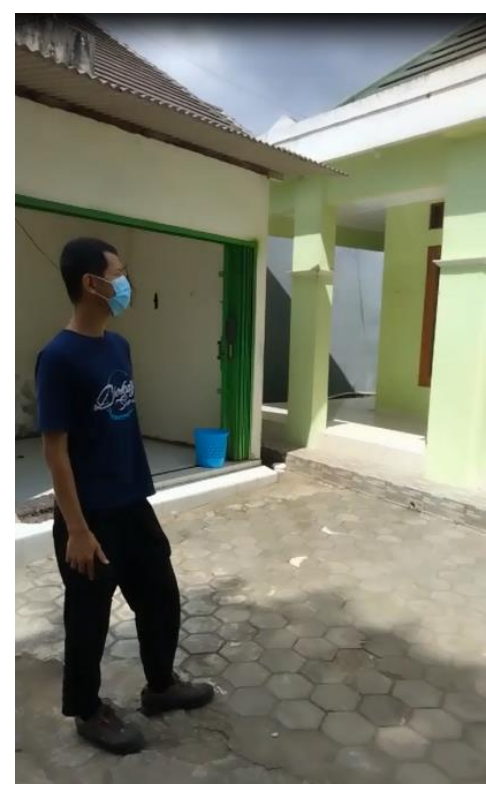

(a)

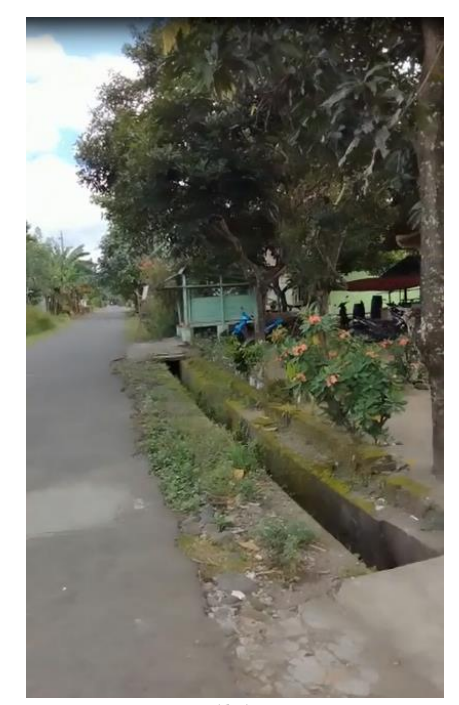

(b)

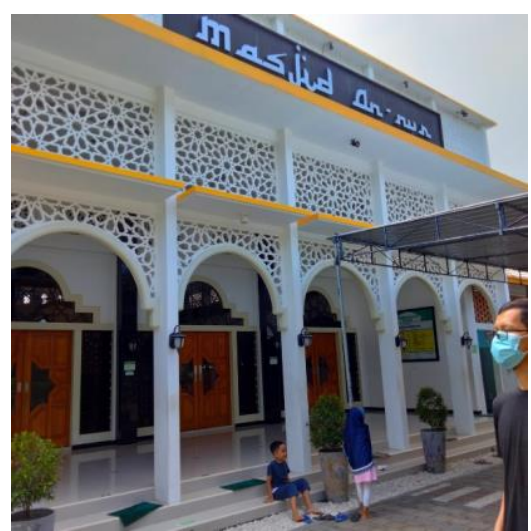

(c)

Gambar 5. Tim Pelaksana Melakukan Survey Lokasi Kandidat Taman Bacaan Masyarakat 


\section{Pengumpulan Materi}

Untuk mewujudkan Taman Bacaan Masyarakat (TBM) yang sesuai dengan lingkungan mitra, tim pelaksana mengumpulkan materi sebagai referensi. Buku-buku yang dibeli adalah buku pengetahuan alam terutama kebumian, peta, buku ketrampilan, buku mengenai wawasan nusantara, sejarah, dongeng anak, religius dan pengetahuan umum.

Tim pelaksana melakukan pencarian buku-buku baik di toko buku online maupun toko buku konvensional. Toko buku konvensional yang cukup lengkap dengan beragam topik di Yogyakarta seperti di Shopping dan Social Agency. Sedangkan buku online bisa diperoleh di Tokopedia ataupun Shopee.

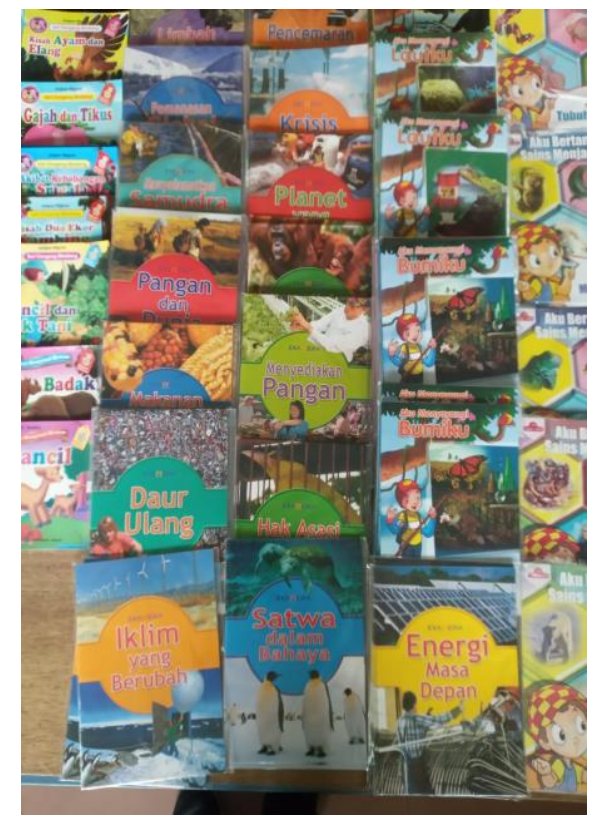

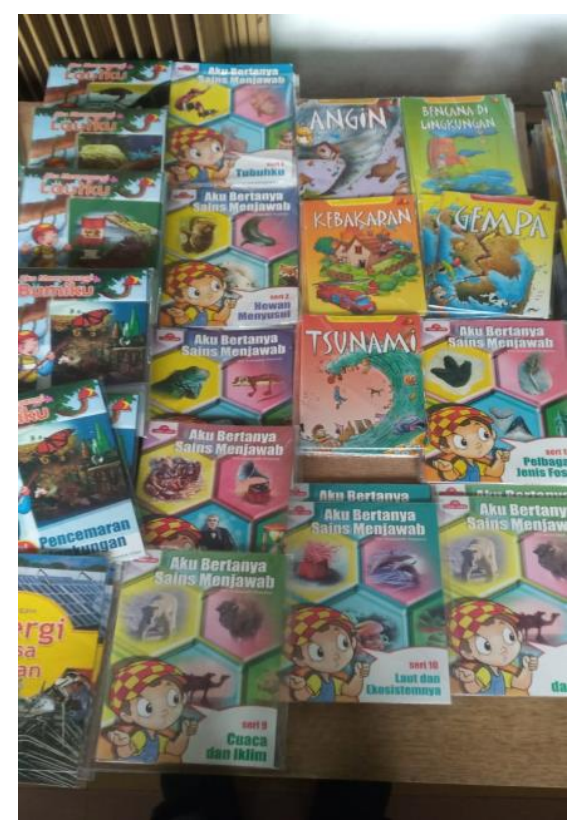

Gambar 6. Tim Pelaksana Melakukan Pengumpulan dan Penyusunan Materi

3. Pengadaan Fasilitas Taman Bacaan Masyarakat

Setelah tim pelaksana kegiatan pengabdian bagi masyarakat ini melakukan pematangan materi buku-buku untuk Taman Bacaan Masyarakat, kemudian tim melakukan pengadaan buku-buku yang disesuaikan kategori buku yang telah direncanakan. Begitu juga pengadaan lemari buku. Desain spanduk sebagai penanda adanya TBM untuk sosialisasi juga dibuat (Gambar 9). Sedangkan sistem peminjaman masih dalam proses pembuatan. 


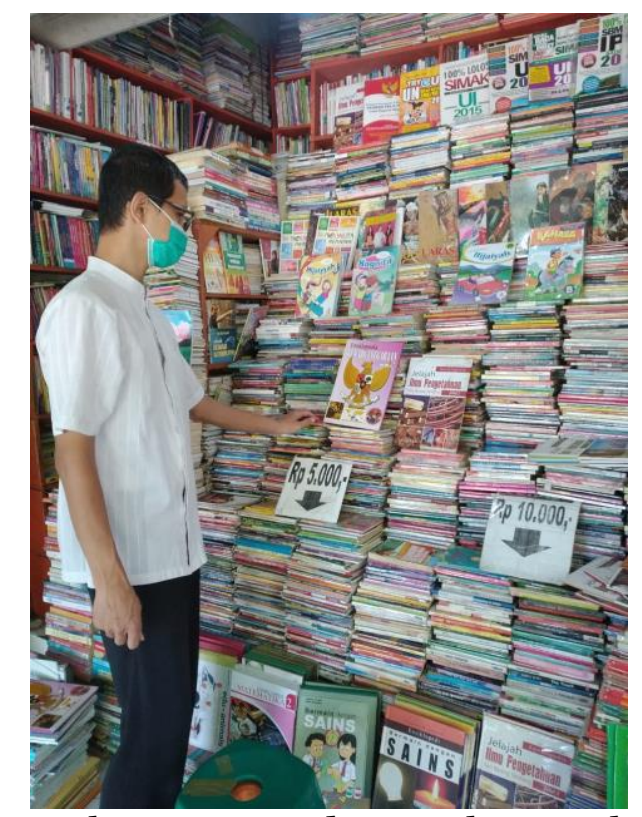

Gambar 7. Pengadaan Buku untuk Taman Bacaan Masyarakat

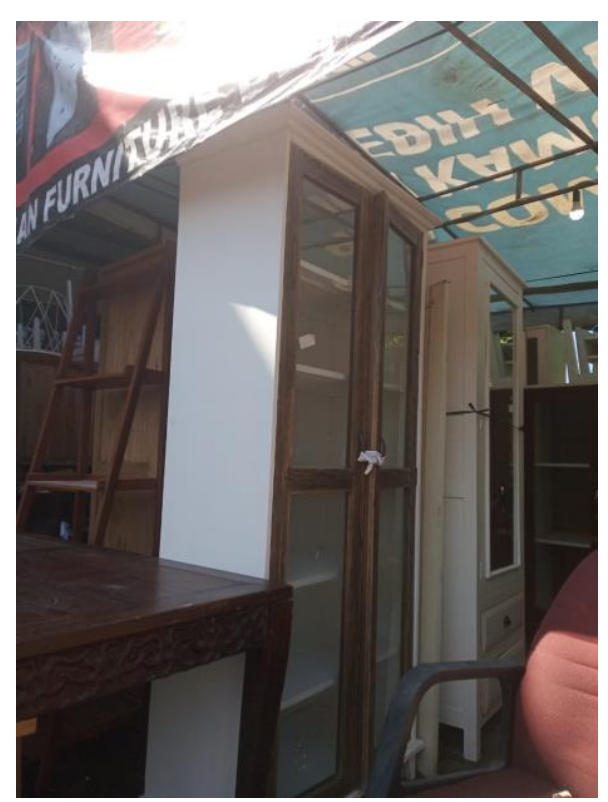

Gambar 8. Pengadaan Lemari Buku untuk Taman Bacaan Masyarakat

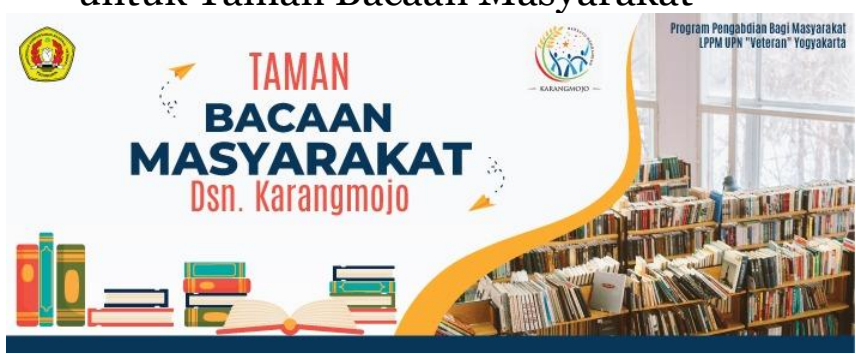

Gambar 9. Desain Spanduk Taman

Bacaan Masyarakat
4. Inventarisasi

Tim pelaksana mendata sarana dan prasarana yang sudah tersedia dan yang dibutuhkan untuk mewujudkan taman bacaan ini. Buku-buku yang telah dibeli kemudian di inventarisasi berdasarkan kategori bukunya. Buku-buku kemudian disampul dan diberi label untuk memudahkan dalam pendataannya.

Pendataan buku dilakukan dengan 2 database yaitu di Microsoft Excel dan aplikasi Handy Library. Aplikasi Handy Library bisa diunduh secara gratis di playstore Data buku akan selalu berkelanjutan. Pencataan menggunakan gadget (laptop maupun handphone) diharapkan dapat memudahkan pengelola nantinya.

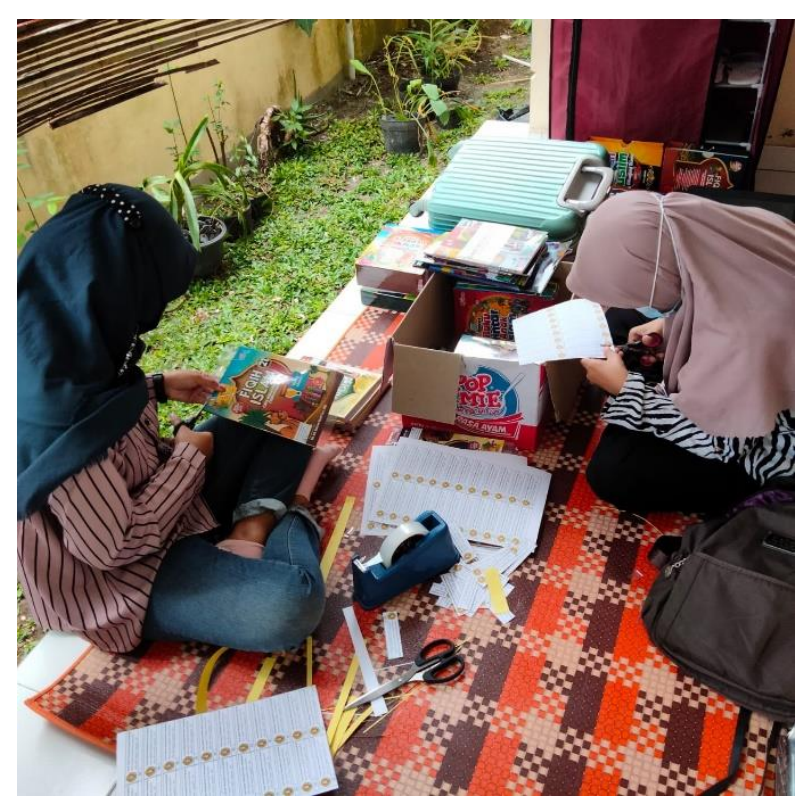

Gambar 10. Tim Pelaksana Melakukan Inventarisasi 
5. Sosialisasi, Pelaksanaan, Monitoring dan Evaluasi

Setelah persiapan sistem siap dijalankan, kemudian dilakukan sosialisasi kepada masyarakat melalui info dari dukuh setempat. Pelaksanaan dilakukan dan monitoring dan evaluasi terus dilakukan untuk menyempurnakan kegiatan ini.

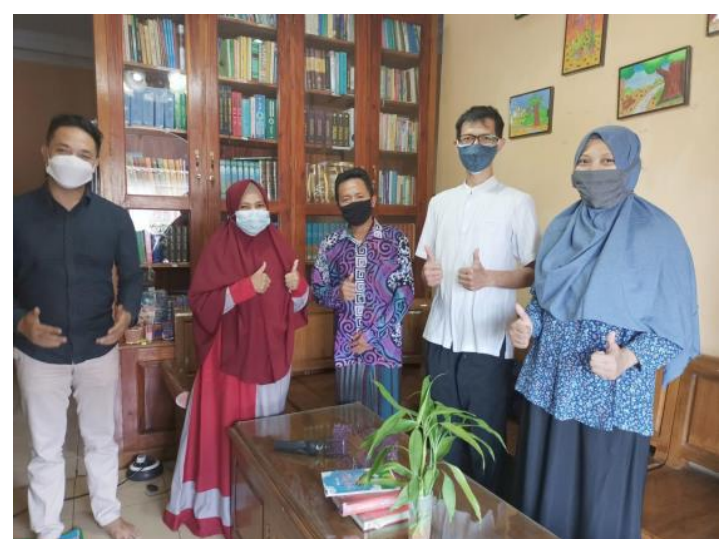

Gambar 11. Koordinasi untuk Sosialisasi Sistem Pengelolaan Taman Bacaan

6. Penyerahan TBM kepada Padukuhan Dusun Karangmojo

Hasil kegiatan ini diserahkan untuk masyarakat Dusun Karangmojo dan pengelolaan diserahkan kepada masyarakat setempat. Hal ini dilakukan agar terjadinya kesinambungan kegiatan setelah diserahkan ke Dusun Karangmojo.

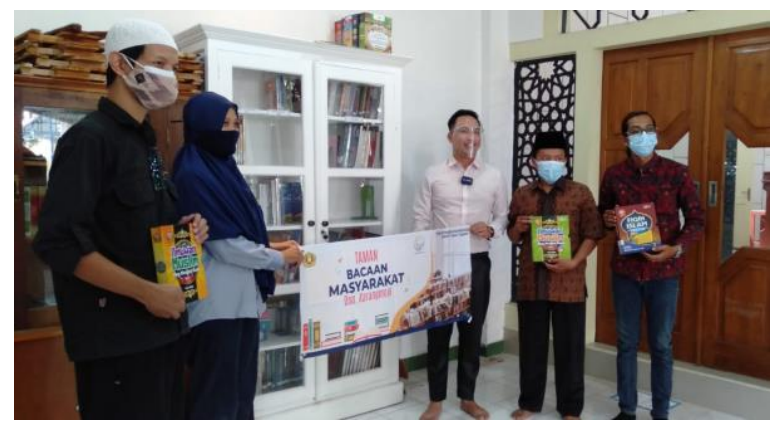

Gambar 12. Serah Terima Taman Bacaan Kepada Pengelola

7. Pembuatan Laporan, Publikasi dan Pendaftaran HKI dan ISBN produk. Setelah kegiatan selesai, dokumentasi, luaran wajib dan laporan dikumpulkan untuk disusun dan diserahkan ke LPPM UPN "Veteran" Yogyakarta.
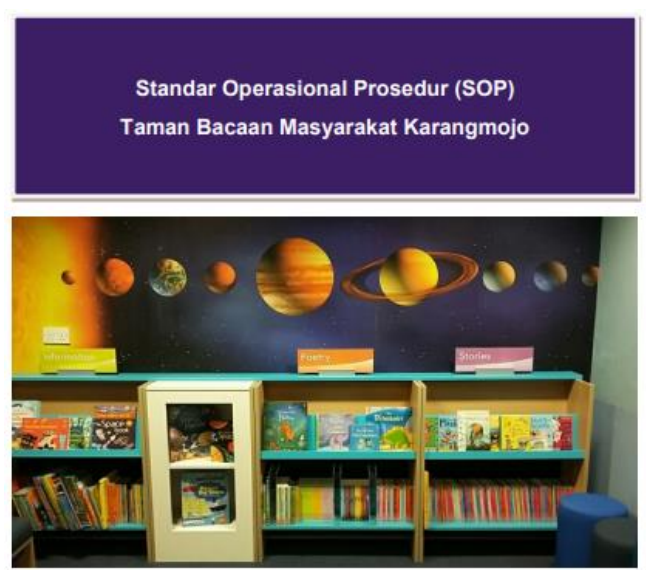

Disusun oleh :

Ristiyan Ragil P, S.T., M.T Ratna Widyaningsih, S.T., M.Eng Yudhy Widya Kusumo, S.Sos., M.A.

Lembaga Penelitian dan Pengabdian Masyarakat UPN "Veteran" Yogyakarta 


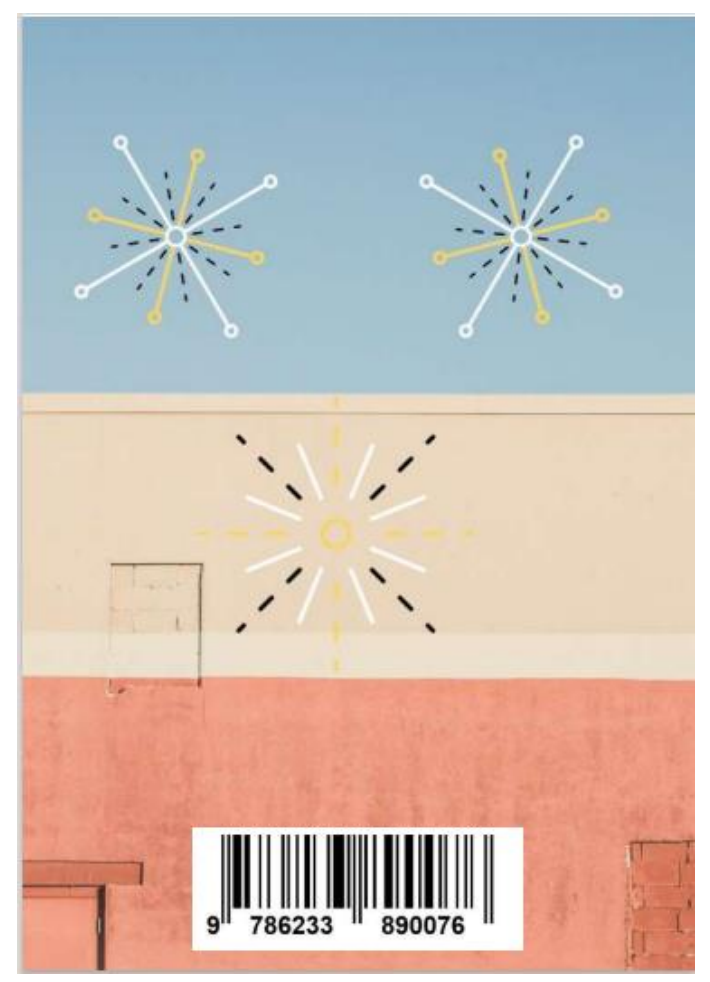

Gambar 13. Luaran Buku yang sudah Ber-ISBN dan memiliki HKI

\section{HASIL DAN PEMBAHASAN}

\section{Hasil}

Taman Bacaan Masyarakat Dusun Karangmojo bertempat di Pelataran Masjid An-Nur Dusun Karangmojo, Kelurahan Purwomartani, Kecamatan Kalasan, Kabupaten Sleman, Provinsi DI Yogyakarta. Lokasi ini merupakan hasil diskusi dengan Kepala Dusun dan Pengurus Masjid. Lokasi ini merupakan tempat yang paling sering dikunjungi oleh masyarakat dan berada dibtengahtengah Dusun Karangmojo, juga memiliki fasilitas untuk membaca di tempat dan memiliki parkir yang luas serta lingkungan yang baik untuk membaca. Lingkungan membaca sangat mempengaruhi minat baca masyarakat. Taman Bacaan Masyarakat Dusun Karangmojo ini menyediakan hampir 400 buku fisik yang dikelompokkan menjadi enam kategori yaitu Buku Anak, Pengetahuan Alam, Pengetahuan Umum, Religi, Kewirausahaan, dan Wawasan Nusantara. Selain menyediakan buku fisik, Taman Bacaan Masyarakat Dusun Karangmojo ini memiliki perpustakaan digital menggunakan aplikasi Handy Library.

\section{Pembahasan}

\section{Menurut Sutarno (2008:127)}

Taman Bacaan Masyarakat pada dasarnya bukanlah sebuah perpustakaan yang harus memenuhi standar nasional perpustakaan seperti standar koleksi, standar sarana dan prasarana, standar pelayanan perpustakaan, standar tenaga perpustakaan, standar penyelenggaraan, dan standar pengelolaan. TBM merupakan sebuah lembaga yang menyediakan bahan bacaan yang dibutuhkan oleh masyarakat sebagai tempat penyelenggaraan pembinaan kemampuan membaca dan belajar. Selain untuk meminjam dan membaca buku, TBM akan dijadikan sebagai tempat untuk berkegiatan produktif.

TBM sebagai media pengembangan budaya baca merupakan tempat mengakses berbagai bahan bacaan, seperti buku pelajaran, buku 
keterampilan praktis, buku Pengelolaan Taman Bacaan Masyarakat pengetahuan, buku keagamaan, buku (2006:2), dijelaskan bahwa fungsi TBM hiburan, karya-karya sastra serta bahan adalah sebagai (1) sarana pembelajaran bacaan lainnya yang sesuai dengan bagi masyarakat untuk belajar mandiri kondisi obyektif dan kebutuhan dan penunjang kurikulum program masyarakat sekitar dan minat baca, baik Pendidikan Luar Sekolah, khususnya bagi aksarawan baru, peserta didik jalur Pendidikan Formal dan Non-Formal (warga belajar), maupun masyarakat umum tanpa batas usia. Di dalam Buku Pedoman Penyelenggaraan Taman Bacaan Masyarakat (2006:9), program keaksaraan; (2) sumber informasi yang bersumber dari berbagai buku dan bahan bacaan lainnya yang sesuai dengan kebutuhan warga belajar dan masyarakat setempat; (3) sumber penelitian (studi kepustakaan) dengan dikemukakan bahwa TBM merupakan memanfaatkan buku-buku dan berbagai sebuah tempat atau wadah yang didirikan dan dikelola, baik oleh masyarakat maupun pemerintah untuk memberikan akses layanan bahan bacaan kepada masyarakat sekitar sebagai sarana pembelajaran seumur hidup dalam rangka peningkatan kualitas hidup masyarakat di sekitar TBM. Dijelaskan pula oleh Sutarno (2008:127) bahwa TBM lebih tepat disebut sebagai fasilitas membaca yang berada di tengah-tengah komunitas (community based library) dan dikelola secara sederhana, swakarsa, swadana dan swasembada oleh masyarakat yang bersangkutan. Dalam hal ini, perlu dikembangkan perasaan ikut memiliki (sense of belongingness) dan ikut bertanggung jawab (sense of responsibility).

Di dalam buku pedoman bahan bacaan lainnya yang tersedia, (4) sumber rujukan yang menyediakan bahan referensi bagi pembelajaran dan kegiatan akademik lainnya; (5) sumber hiburan (rekreatif) yang menyediakan bahan-bahan bacaan yang sifatnya rekreatif untuk memanfaatkan waktu senggang guna memperoleh pengetahuan/informasi baru yang menarik dan bermanfaat.

Dari survey yang telah dilakukan oleh tim pelaksana melalui pengisian kuisioner menggunakan aplikasi Google Form didapatkan sebanyak 57 sampel dengan $92,2 \%$ sampel tersebut merupakan masyarakat Purwomartani. Kuisioner dibagi menjadi dua kategori yaitu untuk usia lebih dari 12 tahun dan usia diantara 4 hingga 12 tahun. Untuk usia diatas 12 tahun terdapat 51 dan rata-rata merupakan Pekerja dan 
Pelajar/Mahasiswa di daerah lebih dari 12 tahun berpendapat bahwa Yogyakarta. Mereka menyambut baik jenis buku yang baik digunakan untuk dan mendukung adanya pembuatan anak adalah buku cetak/fisik dengan Taman Bacaan Masyarakat. Sebanyak 35 sampel (68,7\%) mengaku bahwa di lingkungannya belum terdapat Taman Bacaan Masyarakat maka diperlukan adanya pembangunan TBM di lingkungan mereka. Dari pertanyaan pengadaan buku bacaan, mereka memilih imbang antara buku cetak dan buku digital dikarenakan $74,5 \%$ dari mereka terkadang membaca melalui buku digital dan hanya 9,8\% yang tidak pernah membaca buku digital. Hal ini mempresentasikan bahwa masyarakat Purwomartani dengan usia lebih dari 12 tahun cukup baik minat bacanya dengan menggunakan smartphone dan pertimbangan penyediaan literasi digital cukup potensial untuk masyarakat Purwomartani. Memang benar salah satu keunggulan buku digital adalah fitur 'find keyword' karena dengan waktu singkat dapat menemukan poin yang dicari. Bagi masyarakat Purwomartani membaca buku bukan karena keharusan tetapi memang keinginan mereka sendiri yang ditandai dengan 25 orang menjawab tujuan membaca untuk mengisi waktu luang dan hanya sekitar 7 orang membaca untuk kepentingan tugas sekolah.

Sebanyak 51 sampel dengan usia alasan nyaman dibaca, mengingat penggunaan smartphone yang terlalu lama akan berdampak pada kesehatan. Dan mudah dibaca, karena ukuran smartphone yang tidak terlalu besar membuat anak sulit untuk membaca. Serta lebih menarik, karena anak-anak suka dengan gambar dan warna yang ada pada buku cetak/fisik yang dapat disentuh langsung terutama yang memiliki tekstur khas.

Sebanyak 6 sampel dengan usia antara 4 hingga 12 tahun memilih buku cetak/fisik karena nyaman dibaca. Hal ini memperkuat pendapat orangtua (sampel usia lebih dari 12 tahun) bahwa anak memang membutuhkan buku cetak/fisik. Hal ini juga mempresentasikan bahwa dalam penggunaan Taman Bacaan Masyarakat anak-anak memiliki porsi paling banyak dibandingkan usia diatas 12 tahun, terlihat dari masyarakat Purwomartani dengan usia diatas 12 tahun hamper 50\% memilih buku digital.

Penyediaan buku fisik untuk TBM Dusun Karangmojo ini dilakukan dengan membeli buku di beberapa toko buku yang berada di Yogyakarta. Kemudian Tim Pelaksana memberi sampul serta menginventarisasikan dan 
mengelompokkan kategori buku yang ada. TBM Dusun Karangmojo ini menyediakan 350 buku fisik yang dikelompokkan menjadi enam kategori yaitu Buku Anak, Pengetahuan Alam, Pengetahuan Umum, Religi, Kewirausahaan, dan Wawasan Nusantara. Diharapkan dengan adanya pengelompokkan kategori buku ini, masyarakat mudah dalam mencari dan meminjam buku. Anak-anak juga dapat mengambil buku-buku kategori anak tanpa harus mencari dari kategori buku yang lain.

Sistem peminjaman buku fisik dapat dilakukan secara online dengan aplikasi bantuan bernama Handy Library. Untuk pengelolaan taman bacaan ini, telah dibuatkan akun email tbmannurkarangmojo@gmail.com untuk kemudahan dalam menyimpan database buku dan untuk mengunduh aplikasi Handy Library di playstore. Penggunaan aplikasi ini dimaksudkan untuk memudahkan koordinasi dalam pemindahan data dari satu pengelola ke pengelola lainnya. Kapan pun dan dimana pun pengelola dapat memperbarui data dan mengontrol peminjaman buku. Aplikasi ini sangat mudah digunakan oleh admin atau pengurus TBM Dusun Karangmojo untuk mencatat buku yang sedang atau sudah dipinjam oleh masyarakat. Admin dapat menuliskan nama peminjam dan nomor keanggotaan serta status peminjaman buku. Aplikasi Handy Library memungkinkan memindai ISBN dan memperoleh detail dari sebuah buku, membacanya dan bahkan meminjamkannya secara online. Selain itu, aplikasi Handy Library juga memiliki fitur seperti mencari buku dengan mudah untuk mendapatkan judul, penulis hingga kode ISBN-nya secara online. Inventarisasi buku menggunakan Handy Library yaitu dengan:

1. Install Aplikasi

Diawali dengan login akun Google menggunakan akun email TBM Karangmojo. Kemudian mengunduh aplikasi Handy Library dengan akun tersebut. Aplikasi Handy Library yang gratis hanya mampu menginventaris data maksimal 100 buku, sedangkan untuk TBM Karangmojo ini, aplikasi sudah di upgrade ke Premium Version dimana jumlah buku tidak terbatas dan hanya dibayarkan sekali untuk seumur hidup. Aplikasi ini dapat digunakan oleh lebih dari satu perangkat selama masih menggunakan akun yang sama.

2. Pengaturan Rak Buku (shelves)

Pengaturan rak buku meliputi penambahan, penghapusan dan penamaan ulang rak bisa dilakukan. 
Penambahan rak buku dapat dilakukan dengan memilih tanda (+) di kanan bawah. Penghapusan rak buku dilakukan dengan cara menekan agak lama icon rak buku yang akan dihapus hingga tampil menu pilihan. Selain itu, pada menu ini juga menyediakan penamaan ulang (rename), pengurutan rak buku (move shelf down) dan export data buku pada rak tersebut (export). Hasil file Export data pada menu ini dalam format .xls dan .csv yang dapat dibuka di Microsoft excel. Menu edit bookshelf ini memudahkan pengelola dalam mengubah susunan rak buku. Pengaturan bookshelf juga dapat dilakukan dengan memilih tiga garis di kiri atas aplikasi. Kemudian pilih "Setting" dan pilih edit bookshelves.

3. Input data buku

Aplikasi ini mempunyai fitur pencatatan buku berdasarkan ISBN. Aplikasi ini juga memiliki fasilitas pengelompokan buku berdasarkan kategori (genre) masing-masing dan penempatan buku di rak. Untuk TBM Karangmojo, genre dan nama bookshelf disamakan untuk memudahkan pengelompokkan. Namun hal ini dapat diubah maupun diatur sesuai dengan kebutuhan pengelola terutama jika ada penambahan rak buku fisik.
Pencatatan buku dapat dilakukan dengan scan (pindai) barcode pada kode ISBN. Maka akan muncul informasi lengkap buku tersebut. Scan kode ISBN yang biasanya ada di belakang buku, dengan menekan scan ISBN pada bagian bawah aplikasi. Jika buku tersebut telah terekam di database di internet, maka secara otomatis akan tertulis datanya di aplikasi. Setelah buku tersebut teridentifikasi dan sesuai, maka tekan icon berlogo (+) di kanan atas untuk ditambahkan ke perpustakaan. Klik "SAVE" di bagian bawah aplikasi agar masuk ke database perpustakaan. Namun tidak semua buku koleksi memiliki ISBN. Beberapa buku ada yang sudah terdaftar ISBN namun karena belum tersedia datanya di internet sehingga tidak dapat dilacak datanya. Sehingga proses penginputan dapat dilakukan dengan mencari judul buku dengan cara menekan icon "search online". Jika kedua cara tidak dapat dilakukan, cara terakhir adalah penambahan buku secara manual dengan menekan icon "add manual". Sampul juga dapat diambil gambarnya menggunakan aplikasi tersebut dengan menekan icon Picture. Pada pengelolaan TBM Karangmojo ini, isian "series" diisi 
oleh penomoran kode buku. Sedangkan isian "Genre" dapat disesuaikan oleh pengelola. Setelah isian data buku dilengkapi, kemudian pilih "SAVE".

4. Terdapat lebih dari satu buku dengan judul yang sama

Maka ketika scan barcode, akan ada peringatan: "This book is already exists in your library", maka pilih "Add a copy" agar buku tersebut tetap tercatat. Penomoran buku lebih dari 1 copy dengan menambahkan alphabet di belakang kode buku. Misal PA045.b

5. Pengaturan "Genre"

Pengaturan genre dilakukan agar pengelola dapat menambah atau menghapus kategori buku. Pengaturan ini dilakukan dengan cara memilih simbol tiga garis di kiri atas aplikasi. Kemudian pilih "setting” lalu pilih "Edit Genres".

6. Backup, Export dan Import Data

Pencadangan data sebaiknya dilakukan secara periodik untuk menghindari kehilangan data. Pencadangan data bisa disimpan di google drive (akun TBM Karangmojo) dan di flashdisk. Karena pengelola lebih dari satu orang, maka akan lebih mudah jika penyimpanan dilakukan di google drive. Cara pencadangan data yaitu dengan memilih menu "Backup". Klik semua pilihan, kemudian "OK". Maka akan kita temukan file pencadangan data. Pencadangan dengan OTG (flashdisk), sebaiknya tetap dilakukan menghindari kegagalan penyimpanan di google drive. Serta penyimpanan data dalam bentuk .csv dapat dicetak jika dibutuhkan. Kegiatan Export data dimulai dengan memilih menu “export”. Klik keduanya, kemudian pilih "export". Hasil ekspor data ini adalah format .xls dan .csv. Kedua data ini dapat dibuka di Microsoft Excel. Sedangkan proses import data, dimulai dengan memilih menu "import". Pengelola dapat memilih menu menggantikan data lama dengan yang baru (pilih "replace the current data") atau menggabungkan data terbaru dengan data yang lama (pilih "merge with the current data") tidak hanya dilakukan di microsoft excel yang disimpan di flashdisk namun juga dilakukan pencadangan di aplikasi berbasis Android di handphone.

Sistem peminjaman buku harus tercatat melalui aplikasi Handy Library, yaitu dengan:

1. Pilih/tekan buku yang dipinjam, kemudian buku tersebut akan ditampilkan secara detail, dengan 
dua tab bertuliskan "DETAILS" dan "NOTE"

2. Pilih tab "NOTE", kemudian klik tanda pensil di bagian kanan atas, maka akan muncul halaman yang bertuliskan status buku tersebut.

3. Pada kolom "Lend to", isikan nama peminjam. Jika peminjam mempunyai nama yang mirip atau sama dengan anggota perpustakaan yang lain, maka bisa diberikan tambahan nomor anggota di belakangnya. Misal: Ratna-003.

4. Untuk mengisi tanggal peminjaman, klik icon kalender di bagian "Start Date", dan jika ingin dibuat batas waktu peminjaman maka bisa diklik di icon kalender di bagian "Due Date". Silakan memilih tanggal yang sesuai.

5. Setelah selesai, klik "Save" di bagian bawah.

6. Daftar buku yang dipinjam berikut peminjamnya dapat dilihat pada halaman awal, bagian "Lend/Borrow".

7. Terkait dengan poin (1), terdapat cara lain yang lebih praktis, yaitu dengan cara scan ISBN dari buku yang akan dipinjam. Setelah buku tersebut di-scan, akan muncul notifikasi mengenai apa yang akan dilakukan dengan buku tersebut, maka pilih "Lend or Borrow".
Kemudian lakukan proses seperti pada poin (3) dan seterusnya.

Jika peminjam telah mengembalikan buku, maka pengelola menekan lama (hold) buku yang telah dikembalikan, kemudian akan muncul tanda tempat sampah di bagian kanan atas. Tekan icon tersebut, kemudian akan muncul konfirmasi penghapusan, tekan "yes". Maka dengan ini buku tersebut kembali ke rak buku (Shelves)

Penyediaan Perpustakaan Digital untuk TBM Dusun Karangmojo selain menggunakan aplikasi Handy Library juga menggunakan sistem membagi softfile dalam bentuk .pdf melalui flashdisk yang telah diisi 79 ebook. Sistem ini dilakukan dengan menambahkan dan menyalin ebook melalui flashdisk yang dapat digunakan langsung melalui smartphone maupun PC/laptop. Flashdisk yang disediakan TBM Karangmojo berjumlah 24 buah dengan kapasitas 16GB perflashdisk. Diharapkan dengan adanya fasilitas flashdisk ini, selain untuk menyimpan ebook dapat juga digunakan untuk menyimpan file tugas sekolah dari anakanak Dusun Karangmojo dan menyimpan file dokumen desa (Masjid An-Nur).

Sebagai program, tentu saja TBM Dusun Karangmojo selayaknya mampu melaksanakan fungsinya sebagai media 
atau wahana yang dapat menjadi pusat layanan informasi dalam pengembangan ilmu pengetahuan serta sebagai pendorong (stimulasi) terbentuknya masyarakat gemar membaca yaitu masyarakat yang mau dan biasa membaca. Kebiasaan masyarakat dalam membaca dapat menjadi pendorong berkembangnya rasa ingin tahu yang tinggi sehingga pada akhirnya akan memperoleh wawasan yang luas. Kebiasaan membaca pada individu merupakan wujud dari tingginya minat baca individu tersebut. Pengertian minat baca menurut Rachman (1983:16) adalah perwujudan perilaku baca murid yang disebabkan oleh faktor-faktor pendorong tertentu, baik oleh faktor internal dan faktor eksternal, Definisi minat baca lainnya dikemukakan oleh $\mathrm{F}$. Rahim (2008:28) yaitu sebagai keinginan yang kuat disertai usahausaha seseorang untuk membaca. Tingginya minat baca seseorang dapat dilakukan dengan memperoleh bahan bacaan melalui kesadaran sendiri ataupun adanya dorongan dari luar.

TBM Dusun Karangmojo ini sudah digunakan masyarakat khususnya anak-anak dengan membaca di pelataran Masjid saat waktu luang contohnya sebelum mengaji di sore hari. Anak-anak Dusun Karangmojo saat mengunjungi TBM tetap melakukan protokol kesehatan yang dianjurkan oleh pemerintah, serta tidak berkerumun menjadi satu kelompok. Buku yang telah dipinjam dan dibawa pulang oleh masyarakat untuk dibaca di rumah, sudah tertulis pada aplikasi Handy Libray dengan status meminjam buku atas nama anak yang bersangkutan meminjam buku dan nomor keanggotaannya.

\section{PENUTUP}

\section{Simpulan}

Pembuatan Taman Bacaan Masyarakat Dusun Karangmojo berlokasi di Pelataran Masjid An-Nur, lokasi ini merupakan hasil diskusi dengan Kepala Dusun dan Pengurus Masjid. Penyediaan buku fisik untuk TBM Dusun Karangmojo mencapai 350 buku yang terdiri dari enam kategori yaitu Buku Anak, Pengetahuan Alam, Pengetahuan Umum, Religi, Kewirausahaan, dan Wawasan Nusantara. Sistem peminjaman buku fisik dapat dilakukan secara online dengan aplikasi bantuan bernama Handy Library. Penyediaan Perpustakaan Digital untuk TBM Dusun Karangmojo menggunakan sistem membagi softfile dalam bentuk .pdf melalui flashdisk. Masyarakat khususnya anak-anak telah menggunakan fasilitas TBM Dusun Karangmojo dengan tetap melakukan 
protokol kesehatan yang dianjurkan.

Saran

Tim Pelaksana abdimas menyarankan agar kegiatan membaca di Taman Bacaan Masyarakat Dusun Karangmojo selalu dalam protokol kesehatan yang dianjurkan pemerintah dan masyarakat dapat meminjam serta mengembalikan buku sesuai tanggal yang telah ditentukan. Kemudian untuk admin dari aplikasi Handy Library semoga memiliki waktu yang baik untuk melakukan pengecekan buku serta peminjaman maupun pengembalian buku baik buku cetak/fisik dan buku digital.

\section{UCAPAN TERIMA KASIH}

Tim

$$
\text { Pelaksana }
$$

abdimas

mengucapkan terimakasih kepada pihak-pihak yang terkait dalam pembuatan Taman Bacaan Masyarakat Dusun Karangmojo, yang telah memberikan kontribusinya dan menjadikan Taman Bacaan Masyarakat ini dapat dimanfaatkan oleh masyarakat sekitar. Ucapan terimakasih juga diberikan kepada Lembaga Penelitian dan Pengabdian kepada Masyarakat Universitas Pembangunan Nasional Veteran Yogyakarta, Indonesia yang telah memberikan dukungan dana untuk pengabdian ini.

\section{DAFTAR PUSTAKA}

Zuliarso, Eri. Februariyanti, Herny. (2013). Sistem Informasi Perpustakaan Buku Elektronik Berbasis Web. Jurnal Teknologi Informasi DINAMIK Vol 18 No.1 Januari.

Saepudin, Asep. Nisa, Bunga. (2016).

Menumbuhkan Minat Baca

Masyarakat Melalui Taman Bacaan Masyarakat Berbasis Teknologi Informasi. Kwangsan, Vol. 4 No. 1, Edisi Juni 2016. Hal: 43 - 54.

Astuti, Yuli. Nurasmi. (2013). Pengembangan Perpustakaan Digital di Universitas Riau dengan Program Library Management System (SLIMS). Jurnal Gema Pustakawan Vol. 1. No. 1. Mei 2013. Raudah, Hildayati. (2012). Perpustakaan Digital Perpustakaan Masa Depan. Junal Iqra' Volume o6 No.02 Oktober. Hal: 52-58

Irawan, Yudie. Mustafid. Sugiharto, Aris. (2011). Sistem Informasi Perpustakaan Berbasis Web Aplication. Jurnal Sistem Informasi Bisnis. Hal: 70-73.

Buku Pedoman Penyelenggaraan Taman Bacaan Masyarakat. 2006. Jakarta: Direktorat Dikmas.

Rahmat, J. 2014. Peran PKBM dalam meningkatkan mutu pengelolaan program PAUDNI di Privinsi Jawa 
Tengah dan DI Yogyakarta. Jurnal Pedagogia. Vol. 1 No. 2 Desember 2014.

Sutarno. 2008. Membina Perpustakaan Desa. Jakarta: Sagung Seto.

Sutisna, A. (2015). Pengembangan Model Bimbingan Teknis Berkelanjutan dalam Meningkatkan Kompetensi Tutor Paket C. Jurnal Ilmiah VISI Vol. 10 No. 2 Desember 2015.

Rachman, A., dkk. 1983. Minat Baca Murid Siswa Sekolah Dasar di Jawa Timur. Jakarta: Pusat Pembinaan dan Pengembangan Bahasa.

Rahim, F. 2008. Pengajaran Membaca di Sekolah Dasar. Jakarta: PT Bumi Aksara.

Kurniasih, Nunung. 2016. Optimalisasi Penggunaan Media Sosial untuk Perpustakaan. Prosiding Makalah Seminar Nasional. Juni. Hal: 1-9. 